\title{
Awareness and Practice among Parents of Type-1 Diabetic Children and Adolescent and their Glycemic Status
}

\author{
Fahmida Rahman ${ }^{1}$, Bedwora Zabeen ${ }^{1}$, Abdul Baki ${ }^{1}$ and Hamoida Khanum ${ }^{2,3 *}$ \\ ${ }^{1}$ Pediatric Department, Ma and Shishu Hospital, Birdem General Hospital, Bangladesh \\ ${ }^{2}$ Department of Public Health, American International University, Bangladesh (AIUB) \\ ${ }^{3}$ Parasitology Branch, Department of Zoology, University of Dhaka, Bangladesh \\ *Corresponding author: Hamida Khanum, Professor, Department of Zoology, University of Dhaka, Bangladesh
}

\section{ARTICLE INFO}

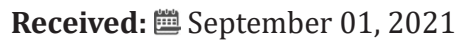

Published: 慧 September 13, 2021

Citation: Fahmida Rahman, Bedwora Zabeen, Abdul Baki, Hamoida Khanum. Awareness and Practice among Parents of Type-1 Diabetic Children and Adolescent and their Glycemic Status. Biomed J Sci \& Tech Res 38(4)-2021. BJSTR. MS.ID.006194.

\begin{abstract}
Diabetes is a long-term condition that can have a major impact on the life of a child or young persons, as well as their family or caregivers. In addition to insulin therapy, diabetes management should include education, support and access to need for psychological services. To study the awareness and diabetes care practice among parents of type 1 diabetic children and adolescents. This is a cross sectional study which included 101 participants who attended in Changing Diabetes in Children (CDIC), BIRDEM, from March 2019 to June 2019. Participants are parents of type 1 Diabetic children and adolescents between 07-18 years of age. Both open ended and close ended question was used. Data were compiled and analyzed using Statistical (SPSS) version 24. Parents of total 101 patients were interviewed over the study period. Among them Eighty-four (84.2\%) respondents were aware about sign and symptoms of Diabetes, $60.4 \%$ respondents gave their children balanced diet, $78.2 \%$ parents practiced checking blood glucose level by glucometer regularly and 95\% parents checked HbA1C level three monthly. HbA1c level was significantly lower among the urban population $(p=0.003)$. Those who completed secondary education had well control than those completing primary education $(p=0.002)$. Those who maintained healthy lifestyle had significantly good control $(p=0.008)$. Those attending the health education class regularly had good control ( $p=0.002)$. Association of control of diabetes and knowledge of complication was analyzed, and it was significant among those parents who have enough knowledge about diabetes and who are aware of diabetes had significantly good control of glycemic status.
\end{abstract}

\section{Introduction}

Diabetes Mellitus (DM) type 1 is a metabolic disorder, characterized by a partial or complete deficiency of the hormone insulin production, resulting from the destruction of pancreatic beta cells, usually caused by the auto immune or idiopathic process. It can occur in a quick and progressive way in children and adolescents [1]. Possible risk factors for type 1 diabetes include [2]: Genetics (genetic marker is located on chromosome 6 and it's a human leukocyte antigen), Family history, Other autoimmune disease, including thyroid disease, Addison's disease, celiac disease, and autoimmune gastritis, Viral infection early in life, Early dietary introduction of cereal and gluten. In addition to insulin therapy, diabetes management should include education, support and access to psychological services need.

In this sense, the American Diabetes Association (ADA) recommends that schools teachers who are trained on and knowledgeable about diabetes so that they can provide disease management and a care environment to children and adolescents with T1D needs, especially diabetic emergencies [3]. A variety of 
genetic conditions (such as maturity-onset diabetes in the young) and other conditions (such as cystic fibrosis-related diabetes) may also lead to diabetes in children and young people [4]. In order for people with T1DM to maintain normal blood glucose levels (BGLs; norm glycaemia) and reduce the potential microvascular, macrovascular and neurologic complications that are associated with poor glycemic control, a daily management routine is required (The Diabetes Control and Complications Trial Research Group [DCCT], 1993). This daily management routine includes blood glucose monitoring (BGM), insulin administration, controlling dietary intake and partaking in physical activity [5].

The main immunological markers of pancreatic compromise are the anti-islet, anti-insulin and anti-glutamic acid decarboxylase (GAD) antibody levels present in $90 \%$ of patients at the time of diagnosis. Diabetes type 1 habitually occurs in children and adolescents. The main goal of treatment is to prevent the appearance or progression of chronic complications, such as microvascular (diabetic retinopathy, nephropathy and neuropathy) and macrovascular (cerebral vascular accident and peripheral arterial disease) complications, simultaneously minimizing the risks of acute complications such as severe hypoglycemia [6].

The therapeutic approach involves various levels of action, such as insulin therapy, dietary guidance, acquisition of knowledge about the disease, the ability to self-apply insulin, and selfmonitoring of glycaemia, maintenance of regular physical activity and psychosocial support [7]. The treatment of diabetes affects basic aspects of everyday life and this difficulty is reflected in their blood glucose level and body weight and may in great part be due to the lack of appropriate perception of the disease and its management resulting in poor compliance and hence suboptimal glycemic control [8].

Life with type 1 diabetes (T1DM) requires extensive selfcare and comprehensive knowledge. This implies that support for parents is needed concerning how to maintain a positive role in the relationship with their child. These approaches should be embedded in health care services in order to reduce parents' stress and empower them in supporting their child's self-care [9]. Type 1 diabetes (T1D) is one of the most common chronic childhood diseases, family functioning, or parent - child relationship quality, has been linked to both metabolic control and psychosocial adjustment in youth with T1D. These findings support the need for familybased interventions that reduce family conflict while promoting family cohesion and supportive involvement [10]. Type 1 diabetes accounts for $5-10 \%$ of the total cases of diabetes worldwide. The global incidence of type 1 diabetes in children below 14 years is increasing with an estimated overall annual increase of around 3\%. The prevalence of type 1 diabetes for United States residents aged
0-19 years is 1.7 per 1000. In Saudi Arabia, the incidence rate was estimated among children between 0-14 years in 2003 to be 12.3 cases per 100,000 per year [11].

The incidence of type 1 diabetes (T1DM) has been increasing all over the world. Chronic complications of diabetes such as retinopathy, neuropathy, coronary heart disease and nephropathy, which are still present, might be prevented. Type 1 Diabetes (T1D) affects about one in every 400 to 600 children and adolescents which translates to approximately 186,300 youth under the age of 20 [12]. Lifestyle is an important determinant of glycemic control in diabetic type 1 and 2 patients. The treatment of DM1 interferes in the lifestyle, is complicated, painful, depends on self-discipline and is essential to the patient's survival. The therapeutic approach involves various levels of action, such as insulin therapy, dietary guidance, acquisition of knowledge about the disease, the ability to self-apply insulin, and self-monitoring of glycaemia, maintenance of regular physical activity and psychosocial support.

In DM1, the important of following a balanced diet, adopting knowledge about the correct consumption of carbohydrates, proteins and fats. Observation of the quantities and qualities required of each food group enables glycemic control and prevention of complications; and adhesion to treatment is the key to attaining the objectives desired [13]. This is especially true for parents of very young children who, themselves, are developmentally unable to assume the role of diabetes manager [14]. They also emphasize that sustained efficacy of these skills is critical to avoid diabetes- related complications. Follansbee (1989) asserted that "knowledge of diabetes care seems to be a necessary, but not sufficient, prerequisite of good self -management, adherence and metabolic control". Because of the complexities involved in diabetes management, children need knowledge and skills 'as a beginning step' towards compliance with a diabetes regimen and metabolic control [11]. Type 1 diabetes among children are becoming increasingly apparent. The development of Type 1 diabetes in early age is likely to be associated with earlier development of complications. As co-morbid characteristics of insulin resistance are commonly present at diagnosis or appear early in the course of Type 1 diabetes, they should be screened earlier, so complications of long-standing diabetes will be diagnosed.

\section{Acute Complication in Children with Type 1 Diabetes}

It was reported that, among the central complications of type I children's diabetes is the Diabetic ketoacidosis (DKA) and severe hypoglycemia. Although that both of them are life-threatening, yet they can be prevented. US children with type 1 diabetes are at high risk for DKA (8 per 100 patient-years) and severe hypoglycemia 
(19 per 100 patient-years [15]. Diabetic ketoacidosis often leads to an emergency department (ED) visit and hospital admission and contributes to the high costs of care for children with type 1 diabetes. Cerebral edema, a devastating complication of DKA, is one of the leading causes of mortality among children with type 1 diabetes. Children with type 1 diabetes can be subjected to serious and acute complications among them: Poor glycemic control, family and school problems, low socioeconomic status, ethnicity, sex, and lack of adequate health insurance have been reported.

\section{Methods and Materials}

The study is cross sectional study. Parents of Type 1 diabetic children who attended CDIC (Changing diabetes in Children Program) pediatric outpatient departments in BIRDEM General Hospital- 2, (Segunbagicha) in Dhaka were included consecutively. The study was carried out from March 2019 to June 2019. Face to face interview were taken by using a questionnaire was designed based on objectives. The specific objective was measured by using appropriate statistical tests.

\section{Ethical Issues}

Taken approval was obtained from the ERB, AIUB.

\section{Results}

\section{Socio-Demographic Information}

In the present study, out of total 101 participants about 42 percent respondents age is more than 46 years, however there is a gap between male and female participants age i.e. 49.3 percent male respondents age is $46+$ years and 23.3 percent female age are $46+$ years. Female respondents mean (SD) age in years is 37.70 (8.74 and male is 44.96 (9.90), Table 1 shows respondents detail age in years by their sex (Table 1 and, Figure 1). Out of total respondents nearly half of the respondents live in the Urban area, 34.7 percent Rural and 16.8 percent lives in the semi urban area (Table 2). Majority respondents (50.5\%) respondents completed Higher Secondary Certificate (HSC) and above, however there is significant gap between male and female educational status. Study findings also indicate about 10 percent respondents have no education and there is also gap between male Vs female (Figure 1). Out of total respondents', majority (50.5\%) respondents completed Higher Secondary Certificate (HSC) and above, however there is significant gap between male and female educational status. Study findings also indicate about 10 percent respondents have no education and there is also gap between male Vs female (Figure 1).

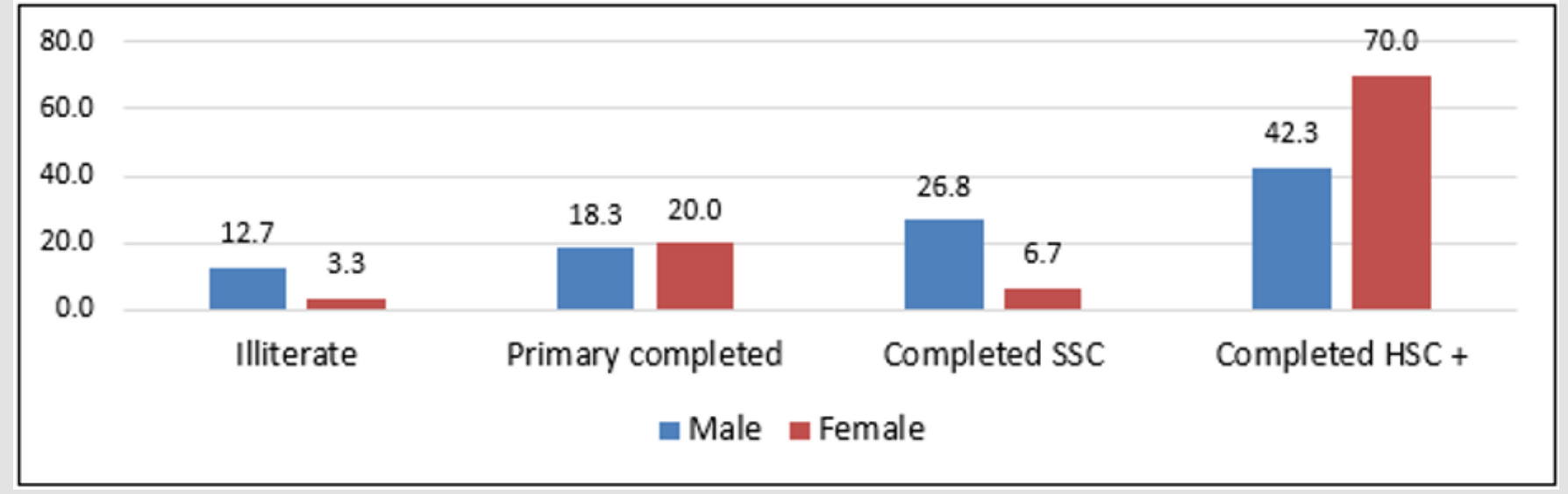

Figure 1: Literacy status of the respondents.

Table 1: Distribution study participants according to age and sex.

\begin{tabular}{|c|c|c|c|c|c|c|c|}
\hline \multicolumn{7}{|c|}{ Distribution study participants according to age and sex } & \multirow{2}{*}{$\begin{array}{c}\text { Significant } \\
\text { level of } x 2 \text { test }\end{array}$} \\
\hline & \multicolumn{2}{|c|}{ Male } & \multicolumn{2}{|c|}{ Female } & \multicolumn{2}{|c|}{ All } & \\
\hline Age in years & Number & Percent & Number & Percent & Number & Percent & \multirow{7}{*}{$\mathrm{p}=.051$} \\
\hline$<=30$ years & 8 & 11.3 & 8 & 26.7 & 16 & 15.8 & \\
\hline 31-35 years & 7 & 9.9 & 7 & 23.3 & 14 & 13.9 & \\
\hline $36-40$ years & 7 & 9.9 & 3 & 10 & 10 & 9.9 & \\
\hline 41-45 years & 14 & 19.7 & 5 & 16.7 & 19 & 18.8 & \\
\hline $46+$ years & 35 & 49.3 & 7 & 23.3 & 42 & 41.6 & \\
\hline Total & 71 & 100 & 30 & 100 & 101 & 100 & \\
\hline Mean (SD) & \multicolumn{2}{|c|}{$44.96(9.90)$} & \multicolumn{2}{|c|}{$37.70(8.74)$} & \multicolumn{2}{|c|}{$42.80(10.09)$} & \\
\hline
\end{tabular}


During face-to-face interview with respondents, respondent's occupational information was collected and found nearly half (49.5 percent) of the respondents are occupation is household work and there is a huge (36.6\% Vs $80.0 \%$ ) difference between male and female respondents. Out of total respondents about 23 percent are doing services (govt./private), 12.9 percent doing business and another 14.9 percent engaging other profession. Out of total respondents, nearly half of the respondents live in the Urban area, 34.7 percent Rural and 16.8 percent lives in the semi urban area (Table 2). Regarding respondent's occupational information was collected and found nearly half (49.5 percent) of the respondents are occupation is household work and there is a huge $36.6 \%$ Vs $80.0 \%$ ) difference between male and female respondents. Out of total respondents about 23 percent are doing services (govt./ private), 12.9 percent doing business and another 14.9 percent engaging other profession (Table 3) Study data clearly indicate majority children duration of diabetic is more than 9 years and there is significant gap between boys and girls (Table 4). Diabetic children present age was asked to study participants and found overall mean (SD) age in years is 14.89 (3.15) and there is big gap between boys and girls. Out of total children with diabetic age in years was 11 to 19 years and there is no significant difference. Among children, the duration of diabetic and found one fifth of the children duration of diabetic is less than equals 4 years. During face-to-face interview with respondents a specific question ("Any one of your family members having diabetic?") was asked to respondents to find out their family members having diabetic. Out of total respondents' majority (66.3 percent) replied "YES" i.e. their family member having diabetic and there is difference between boy and girl's family's diabetic history but no statistically significant (Table 5).

Table 2: Distribution study participants residential area by sex.

\begin{tabular}{|c|c|c|c|c|c|c|c|}
\hline Area & \multicolumn{2}{|c|}{ Male } & \multicolumn{2}{c|}{ Female } & \multicolumn{2}{c|}{ All } \\
level of $x^{2}$ test \\
\hline Urban & 29 & 40.8 & 20 & 66.7 & 49 & 48.5 \\
\hline Rural & 32 & 45.1 & 3 & 10 & 35 & 34.7 \\
\hline Semi Urban & 10 & 14.1 & 7 & 23.3 & 17 & 16.8 & $P=.003$ \\
\hline Total & 71 & 100 & 30 & 100 & 101 & 100 \\
\hline
\end{tabular}

Table 3: Distribution study participants professional category by sex.

\begin{tabular}{|c|c|c|c|c|c|c|}
\hline \multicolumn{7}{|c|}{ Distribution study participants professional category by sex } \\
\hline \\
\hline $\begin{array}{c}\text { Professional } \\
\text { category }\end{array}$ & Number & Percent & Number & Percent & Number & Percent \\
\hline Service & 20 & 28.2 & 3 & 10 & 23 & 22.8 \\
\hline Househol of x2 test \\
\hline Business & 12 & 36.6 & 24 & 80 & 50 & 49.5 \\
\hline Others & 13 & 16.9 & 1 & 3.3 & 13 & 12.9 \\
\hline Total & 71 & 100 & 30 & 100 & 15 & 14.9 \\
\hline
\end{tabular}

Table 4: Distribution of children duration of DM in male and female.

\begin{tabular}{|c|c|c|c|c|c|c|c|}
\hline \multicolumn{7}{|c|}{ Distribution of children duration of DM in male and female } & \multirow{2}{*}{$\begin{array}{c}\text { Significant } \\
\text { level of } x 2 \text { test }\end{array}$} \\
\hline & \multicolumn{2}{|c|}{ Boys } & \multicolumn{2}{|c|}{ Girls } & \multicolumn{2}{|c|}{ All } & \\
\hline DM in years & Number & Percent & Number & Percent & Number & Percent & \multirow{5}{*}{$\mathrm{P}=.633$} \\
\hline$<=4$ years & 7 & 21.2 & 14 & 20.6 & 21 & 20.8 & \\
\hline $5-9$ years & 15 & 45.5 & 25 & 36.8 & 40 & 39.6 & \\
\hline >=10 years & 11 & 33.3 & 29 & 42.6 & 40 & 39.6 & \\
\hline Total & 33 & 100 & 68 & 100 & 101 & 100 & \\
\hline Mean (SD) & \multicolumn{2}{|c|}{7.87 (3.83) } & \multicolumn{2}{|c|}{$8.40(4.10)$} & \multicolumn{2}{|c|}{$8.23(4.01)$} & \\
\hline
\end{tabular}


Table 5: Distribution study participants family's diabetic history by their children sex.

\begin{tabular}{|c|c|c|c|c|c|c|c|}
\hline \multicolumn{7}{|c|}{ Distribution study participants family's diabetic history by their children sex } & \multirow{2}{*}{$\begin{array}{c}\text { Significant } \\
\text { level of } x 2 \text { test }\end{array}$} \\
\hline & \multicolumn{2}{|c|}{ Boys } & \multicolumn{2}{|c|}{ Girls } & \multicolumn{2}{|c|}{ All } & \\
\hline Response & Number & Percent & Number & Percent & Number & Percent & \multirow{3}{*}{$\mathrm{P}=.262$} \\
\hline Yes & 19 & 57.6 & 48 & 70.6 & 67 & 66.3 & \\
\hline No & 14 & 42.4 & 20 & 29.4 & 34 & 33.7 & \\
\hline Total & 33 & 100 & 68 & 100 & 101 & 100 & \\
\hline
\end{tabular}

Respondent's occupational information was collected and found nearly half (49.5 percent) of the respondents are occupation is household work and there is a huge (36.6\% Vs $80.0 \%$ ) difference between male and female respondents. Out of total respondents about 23 percent are doing services (govt./private), 12.9 percent doing business and another 14.9 percent engaging other profession. Out of total respondents, nearly half of the respondents live in the Urban area, 34.7 percent Rural and 16.8 percent lives in the semi urban area (Table 2). However, there is no significant difference between male and female respondent's awareness level (Tables 6\&7). All study participants were asked a question i.e. how they know about their child having diabetes. Study findings shows majority (61.2 percent) replied "OGTT" and 38.8 percent mentioned "RBS" to determine Among the respondents it was found, majority (84.2\%) respondents are aware about sign and symptoms. Regarding the consequence/complication of diabetes by their sex where 86.1 percent respondents know about complications and 13.9 percent are not known. So, there is significant $p$ value between two this group. Table 8 revealed complication of diabetes about nephropathy where 77.2 percent participants are known whether 22.8 percent are not known about nephropathy.

Table 6: Respondents know about their child having diabetes by their sex.

\begin{tabular}{|c|c|c|c|c|c|c|}
\hline \multicolumn{7}{|c|}{ Respondents know about their child having diabetes by their sex } \\
Male & \multicolumn{2}{c|}{ Female } & \multicolumn{2}{c|}{ All } \\
level of x2 test \\
\hline Response & Number & Percent & Number & Percent & Number & Percent \\
\hline OGTT & 34 & 76.1 & 30 & 60 & 64 & 61.2 \\
\hline RBS & 17 & 23.9 & 20 & 40 & 57 & 38.8 \\
\hline Urine Test & 0 & - & 0 & - & 0 & - \\
\hline Total & 51 & 100 & 50 & 100 & 101 & 100 \\
\hline
\end{tabular}

Table 7: Participants know about consequence/complications of diabetes by their sex.

\begin{tabular}{|c|c|c|c|c|c|c|c|}
\hline \multicolumn{7}{|c|}{ Participants know about consequence/complications of diabetes by their sex } & \multirow{2}{*}{$\begin{array}{c}\text { Significant } \\
\text { level of } x 2 \text { test }\end{array}$} \\
\hline & \multicolumn{2}{|c|}{ Male } & \multicolumn{2}{|c|}{ Female } & \multicolumn{2}{|c|}{ All } & \\
\hline Response & Number & Percent & Number & Percent & Number & Percent & \multirow{3}{*}{$\mathrm{P}=.059$} \\
\hline Yes & 58 & 81.7 & 29 & 96.7 & 87 & 86.1 & \\
\hline No & 13 & 18.3 & 1 & 3.3 & 14 & 13.9 & \\
\hline Total & 71 & 100 & 30 & 100 & 101 & 100 & \\
\hline
\end{tabular}

Table 8: Participants know about Nephropathy by their sex.

\begin{tabular}{|c|c|c|c|c|c|c|c|}
\hline \multicolumn{7}{|c|}{ Participants know about Nephropathy by their sex } & \multirow{2}{*}{$\begin{array}{c}\text { Significant } \\
\text { level of } x 2 \text { test }\end{array}$} \\
\hline & \multicolumn{2}{|c|}{ Male } & \multicolumn{2}{|c|}{ Female } & \multicolumn{2}{|c|}{ All } & \\
\hline Response & Number & Percent & Number & Percent & Number & Percent & \multirow{3}{*}{$\mathrm{P}=.196$} \\
\hline Yes & 52 & 73.2 & 26 & 86.7 & 78 & 77.2 & \\
\hline No & 19 & 26.8 & 4 & 13.3 & 23 & 22.8 & \\
\hline Total & 71 & 100 & 30 & 100 & 101 & 100 & \\
\hline
\end{tabular}


There is no significant complications of retinopathy where, 76.2 percent respondents are known about 23.8 percent difference between two groups. There is no significant (Table 9) complications of retinopathy where 76.2 percent respondents are known about 23.8 percent difference between two groups. Out of total about half of the respondents know about neuropathy and rest of the respondents do not have knowledge about neuropathy and fund statistically significant and participants knowledge about neuropathy by their sex (Table 10). To know about respondents knowledge about DKA. Out of total respondents about 44 percent have correct knowledge about "DKA" and there is a difference between male and female respondents and found statistically significant. Table 11 presents detail respondents' knowledge on "DKA" by their sex, and participants knowledge about most accurate method diabetic monitoring by glucometer (55.4 percent) and by HbA1c level (38.6 percent). There is no significant gap between male and female knowledge. A question was asked to all respondents to get an idea i.e. their child maintain healthy life or not? Out of total respondents' majority (82.2 percent) replied "YES" i.e., their child maintains healthy life (Table 12).

Table 9: Participants know about retinopathy by their sex.

\begin{tabular}{|c|c|c|c|c|c|c|c|}
\hline \multicolumn{7}{|c|}{ Participants know about retinopathy by their sex } & \multirow{2}{*}{$\begin{array}{c}\text { Significant } \\
\text { level of } x 2 \text { test }\end{array}$} \\
\hline & \multicolumn{2}{|c|}{ Male } & \multicolumn{2}{|c|}{ Female } & \multicolumn{2}{|c|}{ All } & \\
\hline Response & Number & Percent & Number & Percent & Number & Percent & \multirow{3}{*}{$\mathrm{P}=.131$} \\
\hline Yes & 51 & 71.8 & 26 & 86.7 & 77 & 76.2 & \\
\hline No & 20 & 28.2 & 4 & 13.3 & 24 & 23.8 & \\
\hline Total & 71 & 100 & 30 & 100 & 101 & 100 & \\
\hline
\end{tabular}

Table 10: Participants know about Neuropathy by their sex.

\begin{tabular}{|c|c|c|c|c|c|c|c|}
\hline \multicolumn{7}{|c|}{ Participants know about Neuropathy by their sex } & \multirow{2}{*}{$\begin{array}{c}\text { Significant } \\
\text { level of } x 2 \text { test }\end{array}$} \\
\hline & \multicolumn{2}{|c|}{ Male } & \multicolumn{2}{|c|}{ Female } & \multicolumn{2}{|c|}{ All } & \\
\hline Response & Number & Percent & Number & Percent & Number & Percent & \multirow{3}{*}{$\mathrm{P}=.007$} \\
\hline Yes & 29 & 40.8 & 21 & 70 & 50 & 49.5 & \\
\hline No & 42 & 59.2 & 9 & 30 & 51 & 50.5 & \\
\hline Total & 71 & 100 & 30 & 100 & 101 & 100 & \\
\hline
\end{tabular}

Table 11: Participants know about DKA by their sex.

\begin{tabular}{|c|c|c|c|c|c|c|c|}
\hline \multicolumn{7}{|c|}{ Participants know about DKA by their sex } & \multirow{2}{*}{$\begin{array}{c}\text { Significant } \\
\text { level of } x 2 \text { test }\end{array}$} \\
\hline & \multicolumn{2}{|c|}{ Male } & \multicolumn{2}{|c|}{ Female } & \multicolumn{2}{|c|}{ All } & \\
\hline Response & Number & Percent & Number & Percent & Number & Percent & \multirow{3}{*}{$\mathrm{P}=.009$} \\
\hline Yes & 25 & 35.2 & 19 & 63.3 & 44 & 43.6 & \\
\hline No & 46 & 64.8 & 11 & 36.7 & 57 & 56.4 & \\
\hline Total & 71 & 100 & 30 & 100 & 101 & 100 & \\
\hline
\end{tabular}

Table 12: Participants knowledge about most accurate method diabetic monitoring by their sex.

\begin{tabular}{|c|c|c|c|c|c|c|c|}
\hline \multicolumn{7}{|c|}{ Participants knowledge about most accurate method diabetic monitoring by their sex } & \multirow{2}{*}{$\begin{array}{c}\text { Significant } \\
\text { level of } x 2 \text { test }\end{array}$} \\
\hline & \multicolumn{2}{|c|}{ Male } & \multicolumn{2}{|c|}{ Female } & \multicolumn{2}{|c|}{ All } & \\
\hline Response & Number & Percent & Number & Percent & Number & Percent & \multirow{4}{*}{$\mathrm{P}=.039$} \\
\hline Glucometer & 44 & 62 & 12 & 40 & 56 & 55.4 & \\
\hline Urine Test & 2 & 2.8 & 4 & 13.3 & 6 & 5.9 & \\
\hline $\mathrm{HbA1c}$ & 25 & 35.2 & 14 & 46.7 & 39 & 38.6 & \\
\hline Total & 71 & 100 & 30 & 100 & 101 & 100 & \\
\hline
\end{tabular}


To know about respondents' knowledge about DKA. Out of total respondents about 44 percent have correct knowledge about "DKA" and there is a difference between male and female respondents and found statistically significant. Table 11 presents detail respondents' knowledge on "DKA" by their sex, and participants knowledge about most accurate method diabetic monitoring by glucometer (55.4 percent) and by HbA1c level (38.6 percent). There is no significant gap between male and female knowledge. A question was asked to all respondents to get an idea i.e. their child maintain healthy life or not? Out of total respondents' majority (82.2 percent) replied "YES" i.e., their child maintains healthy life (Table 12).

Out of total respondents' majority (66.3 percent) respondents mention name of "Glucometer" i.e., by using Glucometer they feel comfort for monitoring their child diabetes level. A question was asked to respondents during face-to-face interview with respondents to know about their knowledge about hypoglycemia. Out of total respondent majority (81.2 percent) replied "YES" i.e. they know about hypoglycemia and there is significant gap between male and female respondents. Table B-09 present detail response by their sex (Tables 12\&13). A subsequent question was also asked to all respondents for determining respondent knowledge about management of hypoglycemia. Out of total respondent majority (74.3 percent) know about anagement of hypoglycemia and there is no significant difference between male and female participants response. Table B-10 present detail information in this regard. Regarding the children insulin taking status, in replied this question majority respondents replied "YES" i.e. their child taking regular insulin as per the physician advice and found significant difference between male (64.4\%) and female (35.6\%) response (Table 14). During face-to-face interview with using a prescribe questionnaire to find out study participant's child performed his/her own blood sugar test. Out of total respondent majority (78.2 percent) replied "YES" i.e. their child performing their blood sugar by using glucometer. However about 23 percent respondents replied "NO" i.e. their child not performed blood sugar test. According to study participants response majority (59.4 percent) child received insulin as per the physician specific advice and there is small gap between male and female respondents but is not statistically significant.

Table 13: Participants knowledge about most accurate method diabetic monitoring by their sex.

\begin{tabular}{|c|c|c|c|c|c|c|}
\hline \multicolumn{7}{|c|}{ Participants knowledge about hypoglycemia by their sex } \\
\hline \\
\hline Response & Number & Percent & Number & Percent & Number & Percent \\
level of x2 test \\
\hline Yes & 59 & 83.1 & 23 & 76.7 & 82 & 81.2 \\
\hline No & 12 & 16.9 & 7 & 23.3 & 19 & 18.8 \\
\hline Total & 71 & 100 & 30 & 100 & 101 & 100 \\
\hline
\end{tabular}

Table 14: Child taking regular insulin by respondents' sex.

\begin{tabular}{|c|c|c|c|c|c|c|c|}
\hline \multicolumn{7}{|c|}{ Child taking regular insulin by respondents' sex } & \multicolumn{2}{c|}{$\begin{array}{c}\text { Significant } \\
\text { level of x2 test }\end{array}$} \\
\hline Response & Number & Percent & Number & Percent & Number & Percent \\
\hline Yes & 50 & 70.4 & 15 & 50 & 65 & 64.4 & P=.050 \\
\hline No & 21 & 29.6 & 15 & 50 & 36 & 35.6 & 100 \\
\hline Total & 71 & 100 & 30 & 100 & 101 & \\
\hline
\end{tabular}

Some Association Between Participants and Type 1 Diabetic Children About Good and Poor Control HBA1c Level (Tables A-E)

Table A: Child HbA1C level and residence.

\begin{tabular}{|c|c|c|c|c|c|c|c|}
\hline \multicolumn{7}{|c|}{ Child HbA1C level and residence } & \multirow{3}{*}{$\begin{array}{c}p \text { value of } X 2 \\
\text { test }\end{array}$} \\
\hline \multirow{2}{*}{ HbA1c level } & \multicolumn{2}{|c|}{ Urban } & \multicolumn{2}{|c|}{ Rural } & \multirow{2}{*}{$\begin{array}{c}\text { All } \\
\text { Number }\end{array}$} & \multirow[b]{2}{*}{ Percent } & \\
\hline & Number & Percent & Number & Percent & & & \\
\hline$<=8.50$ & 39 & 79.6 & 32 & 61.5 & 71 & 70.3 & \multirow{2}{*}{0.003} \\
\hline$>8.50$ & 10 & 20.4 & 20 & 38.5 & 30 & 29.7 & \\
\hline Total & 49 & 100 & 52 & 100 & 101 & 100 & \\
\hline
\end{tabular}

Note: There is significant $p$ value $(p=0.003)$ between urban and rural participant's children where glycemic control are good. 
Table B: Child HbA1C level and level of education.

\begin{tabular}{|c|c|c|c|c|c|c|c|}
\hline \multicolumn{7}{|c|}{ Child HbA1C level and level of education } & \multirow{3}{*}{$\begin{array}{c}p \text { value of } X 2 \\
\text { test }\end{array}$} \\
\hline \multirow{2}{*}{ HbA1c level } & \multicolumn{2}{|c|}{ Upto Primary } & \multicolumn{2}{|c|}{ Secondary + } & \multirow{2}{*}{$\begin{array}{c}\text { All } \\
\text { Number }\end{array}$} & \multirow[b]{2}{*}{ Percent } & \\
\hline & Number & Percent & Number & Percent & & & \\
\hline$<=8.50$ & 11 & 37.9 & 54 & 75 & 65 & 64.4 & \multirow{2}{*}{0.002} \\
\hline$>8.50$ & 18 & 62.1 & 18 & 25 & 36 & 35.6 & \\
\hline Total & 29 & 100 & 72 & 100 & 101 & 100 & \\
\hline
\end{tabular}

Note: There is significant $\mathrm{p}$ value change between primary level and secondary level education participant's child where HbA1C level are well controlled.

Table C: Child HbA1C level and attended CDIC HE.

\begin{tabular}{|c|c|c|c|c|c|c|c|}
\hline \multicolumn{7}{|c|}{ Child HbA1C level and attended CDIC HE } & \multirow{3}{*}{$\begin{array}{c}p \text { value of } X 2 \\
\text { test }\end{array}$} \\
\hline \multirow{2}{*}{ HbA1c level } & \multicolumn{2}{|c|}{ Yes } & \multicolumn{2}{|c|}{ No } & \multirow{2}{*}{$\begin{array}{c}\text { All } \\
\text { Number }\end{array}$} & \multirow[b]{2}{*}{ Percent } & \\
\hline & Number & Percent & Number & Percent & & & \\
\hline$<=8.50$ & 50 & 62.5 & 7 & 29.2 & 57 & 54.8 & \multirow{2}{*}{0.002} \\
\hline$>8.50$ & 30 & 37.5 & 14 & 70.8 & 44 & 45.2 & \\
\hline Total & 80 & 100 & 21 & 100 & 101 & 100 & \\
\hline
\end{tabular}

Note: There is significant change between the participants who attended health education class in CDIC, those children's glycemic control are good.

Table D: Child HbA1C level and parent know about consequence of diabetes.

\begin{tabular}{|c|c|c|c|c|c|c|c|}
\hline \multicolumn{7}{|c|}{ Child HbA1C level and parent know about consequence of diabetes } & \multicolumn{2}{c|}{$\begin{array}{c}\text { Noll } \\
\text { p value of X2 } \\
\text { test }\end{array}$} \\
\hline \multirow{2}{*}{ HbA1c Level } & \multicolumn{2}{|c|}{ Yes } & \multicolumn{2}{c|}{ No } & Number & Percent \\
\cline { 2 - 8 } & Number & Percent & Number & Percent & 67 & 65 & 0.007 \\
\hline$<=8.50$ & 55 & 78.6 & 10 & 63.4 & 34 & 35 & 100 \\
\hline$>8.50$ & 15 & 21.4 & 21 & 100 & 101 & \\
\hline Total & 70 & 100 & 31 & 63.6 & 100 & \\
\hline
\end{tabular}

Note: In this table show significant change between those participants who knows about the consequence of complication of diabetes.

Table E: Child HbA1C level and residence.

\begin{tabular}{|c|c|c|c|c|c|c|c|}
\hline \multicolumn{7}{|c|}{ Child HbA1C level and children maintaining healthy lifestyle } & \multirow{3}{*}{$\begin{array}{c}p \text { value of } X 2 \\
\text { test }\end{array}$} \\
\hline \multirow{2}{*}{ HbA1c level } & \multicolumn{2}{|c|}{ Yes } & \multicolumn{2}{|c|}{ No } & \multirow{2}{*}{$\begin{array}{c}\text { All } \\
\text { Number }\end{array}$} & \multirow[b]{2}{*}{ Percent } & \\
\hline & Number & Percent & Number & Percent & & & \\
\hline$<=8.50$ & 56 & 75.7 & 18 & 66.7 & 74 & 73.3 & \multirow{2}{*}{0.008} \\
\hline$>8.50$ & 18 & 24.3 & 9 & 33.3 & 27 & 26.7 & \\
\hline Total & 74 & 100 & 27 & 100 & 101 & 100 & \\
\hline
\end{tabular}

Note: Above variables non-parametric test (chi-square) values indicate all indicators are statistically significant i.e., study participants children level of HbA1c level and tested variables have positive association.

\section{Discussion}

Mellitus (Type1diabetes (T1D) is a chronic disease that unusually appears in the pediatric age, whose proper management avoids short and long-term complications [16]. Diabetes DM) type1 is a metabolic disorder, characterized by a partial or complete deficiency of the hormone insulin production, resulting from the destruction of pancreatic beta cells, usually caused by the auto immune or idiopathic process. [1]. This study highlights parents' different and varying needs for information when living with a child or adolescent with T1DM. Overall, the results confirm the role of electronic communication as complementary and important [1720].

Parenting a child or adolescent with T1DM involves the same hardships and in addition, there is the disease, which complicates things from time to time with varying intensity and affects all members of the family [21]. The education of individuals with diabetes mellitus should involve a specialized multidisciplinary team approach. The effectiveness of this patient education is largely dependent on adequate knowledge by health care professional [22]. 
Parent's knowledge, attitude and practice can promote a healthy, productive learning environment, promote full participation in all curricular and extracurricular activities, achieve glycemic control and help assure effective response in case of diabetes- related emergency and better healthy life [23,24]. Diabetes education must be targeted toward parents to help them to be in possession of relevant management and interpersonal skills for providing some elements of guidance and counseling relating to students with DM when necessary [25]. The proper management of the disease in children and adolescents has been a challenge, because of the presence of behaviors, skills and inadequate knowledge that contribute to non-adherence to treatment and the significant increase in long-term complications [26].

The challenges of T1DM include awareness of the disease which is very poor amongst the general public and also in parents of T1DM children, and this needs to be improved to effectively counter the problem of T1DM $[27,28]$. The general population is unaware of the existence of diabetes in children of 2-5 years of age and believe that it affects only the middle-aged group. Out of total respondent's 86.1 percent respondents know about complications of diabetic and 13 . Ninety Six percent children/adolescent HbA1c level is more than $8.50 / \mathrm{mml}$ and only 4 percent children/adolescent HbA1c level is below $8.50 / \mathrm{mml}$ and there is statistically significant gap, majority 81.2 perc between male and female's children/adolescent HbA1c level. Out of total respondents more than 90 percent attended health education session at CDIC, however there is a significant gap between male and female participation in the health education session at CDIC, BIRDEM-2. Out of total study participants majority (77.2 percent) replied i.e., their child last blood sugar test has been performed within the one month and there is a significant difference between male and female participant's children/adolescent blood sugar test status. Overall, eighty seven percent participants replied i.e. their children/adolescent attended health education session on regular basis at CDIC, BIREDM-2, however there is no statistically significant gap between male and female participant's children/ adolescent.

Therefore, considering the criteria for evaluating the effectiveness of the education program: Regular physical activity practice; Change in eating habits; Good psychosocial adaptation; Adherence to the dosage of the medication regimen; Adequate self-monitoring of blood glucose; Reduction of the risk of chronic complications (improvement in glycemic control); Individual's ability to properly correct hypoglycemia and hyperglycemia and the results of this study, it was observed that the education program in diabetes has good efficacy. However, it is necessary to consider and strengthen some important aspects of the management of diabetes to be adequate and provide a better quality of life of affected children [29-36].

\section{Conclusion}

In this study most parent age was 41-46 years. Half of the participants were from urban area and are with HSC education level. 86.1\% parent know the long-term complication of diabetes but only $43.6 \%$ unknown the diabetic ketoacidosis. $82 \%$ parents maintain healthy lifestyle, $60 \%$ patients took balance diet, and $64 \%$ patient took regular insulin. So, in this study significant association of good glycemic control was found those were living in urban area, education level HSC or more, regular attended at CDIC education session and good knowledge about consequence of diabetes and maintain healthy life style.

\section{Competing Interests}

There was no competing interest among the authors.

\section{References}

1. Pedrosa, KarilenaKarlla de Amorim Pinto, Juliana Teixeira Jales Menescal, Arrais, Ricardo Fernando Machado, Regimar Carla, Mororó, et al. (2016) Education effectiveness in diabetes mellitus type 1 management made by children's caregivers. Enfermería Global 44: 115

2. Daphne E Smith-Mash (2016) Type1Diabetes Risk Factors, Genes, ethnicity and geography may all play a role.

3. José V Gutiérrez-M, Florentino CS, Laureano, Pablo MV, Guillermo de C-M, et al. (2018) Teachers' Knowledge About Type 1 Diabetes in South of Spain Public Schools. Diabetes Research and Clinical Practice (2018).

4. (2015) NICE Guideline 18 Methods,2015 National Collaborating Centre for Women's and Children's Health evidence and recommendations. Diabetes (type 1 and type 2) in children and young people: diagnosis and management.

5. Rebecca M, Alison H (2014) Type 1 Diabetes Mellitus (T1DM) selfmanagement in hospital; Is it possible? A literature review a School of Nursing and Midwifery, Flinders University, Adelaide, SA, Australia.

6. Silvia H de Carvalho Sales-Peres, Maria de Fatima Santos Guedes, Letícia Marques Sá, Carlos Antonio Negrato, José Roberto Pereira Lauris (2016) Lifestyle of patients with diabetes mellitus type 1: a systematic review Ciência \& Saúde Coletiva 21(4): 1197-1206.

7. Brink SJ, Miller M, Moltz KC (2002) Education and multidisciplinary team care concepts for pediatric and adolescent diabetes mellitus. J Pediatr Endocrinol Metab 15: 1113-1130

8. EL Hadi MA (2003) Knowledge Attitude and Practices among diabetic children and their relation to glycemic control. A thesis submitted for the requirements of the degree of clinical MD in Paediatrics and Child health. University of Khartoum, Faculty of Medicine.

9. Sam Nordfeldt, Teresia Angarne-Lindberg, Maria Nordwall, Barbro Krevers (2013) Parents of Adolescents with Type 1 Diabetes - Their Views on Information and Communication Needs and Internet Use. A Qualitative Study. PLOS ONE.

10. Bahlool HAA (2017) Assesment of the Knowledge, Attitude and Management Practice of Type 1 Diabetes Mellitus among Primary School Teachers in Tabouk City, Saudi arabia. International Journal of Medicine Research Professionals 3(5): 248-257

11. Roper SO, Amanda C, Joan L, G Cole R, Barbara L. Mandleco, et al. (2009) Type 1 diabetes: children and adolescents' knowledge and questions. Journal of Advanced Nursing 65(8): 1705-1714. 
12. (2019) American Diabetes Association [ADA], Acccess the 2019 Standards of Medical Care in Diabetes.

13. Silvia H de Carvalho Sales-Peres, Maria de Fatima Santos Guedes, Letícia Marques Sá, Carlos Antonio Negrato, José Roberto Pereira Lauris (2016) Lifestyle of patients with diabetes mellitus type 1: a systematic review Ciência \& Saúde Coletiva 21(4): 1197-1206.

14. Lynda Stallwood (2006) Relationship Between Caregiver Knowledge and Socioeconomic Factors on Glycemic Outcomes of Young Children with Diabetes. JSPN 11(3).

15. Michael CR, Ian WG, Carmel ES, Craig ET, Peter A, et al. (2017) Exercise management in type 1 diabetes: a consensus statement. Lancet Diabetes Endocrinol.

16. JA McKnight, S H Wild, M J E Lamb, M N Cooper, TW Jones, et al. (2015) Glycaemic control of Type 1 diabetes in clinical practice early in the $21 \mathrm{st}$ century: an international comparison. Diabet Med J Br Diabet Assoc 32: 1036-1050.

17. Zysberg L, Lang T Graduate School, Gordon College of education, 2Department of Nursing, University of Haifa, Haifa, Israel, Supporting parents of children.

18. Barbara Bohn, Antje Herbst, Martin Pfeifer, Dietmar Krakow, Stefan Zimny, et al. (2015) Impact of physical activity on glycemic control and prevalence of cardiovascular risk factors in adults with type 1 diabetes: a cross-sectional multicenter study of 18,028 patients. Diabetes Care 38: 1536-1543.

19. Quirk H, Blake H, Tennyson R, Randell TL, Glazebrook C (2014) Physical activity interventions in children and young people with type 1 diabetes mellitus: a systematic review with meta-analysis. Diabet Med J Br Diabet Assoc 31: 1163-1173.

20. Miller RG, Mahajan HD, Costacou T, Sekikawa A, Anderson SJ, et al. (2016) A contemporary estimate of total mortality and cardiovascular disease risk in young adults with type 1 diabetes: the Pittsburgh Epidemiology of Diabetes Complications Study. Diabetes Care 39: 2296-2303.

21. Al-Odayni AN, Alsharqi OZ, Mohammad KA, Abdulrahman KAl-A Mohammad H Al-Borie, Ameerah MN Qattan (2013) Children's Glycemic Control: Mother's Knowledge and Socioeconomic Status. Global Journal of Health Science 5(6): 1916-9736 E-ISSN 1916-9744.

22. Prasanna KM, Banshi S, PV Rao, Archana S, Vijay V, et al. (2015) Type 1 diabetes: Awareness, management and challenges: Current scenario in India. Indian Journal of Endocrinology and Metabolism 19.

\section{ISSN: 2574-1241}

DOI: 10.26717/BJSTR.2021.38.006194

Hamoida Khanum. Biomed J Sci \& Tech Res

CC (P) This work is licensed under Creative Commons Attribution 4.0 License

Submission Link: https://biomedres.us/submit-manuscript.php
23. Katz M, Giani E, Laff el L (2015) Challenges and opportunities in the management of cardiovascular risk factors in youth with type 1 diabetes: lifestyle and beyond. CurrDiab Rep 15: 119

24. Anderson BJ, Vangsness L, Connell A, Butler D, Goebel-Fabbri A, et al. (2002) Family conflict, adherence, and glycaemic control in youth with short duration Type 1 diabetes. Diabet Med 19: 635-642.

25. Brito TB, Sadala MLA (2009) Diabetes mellitus juvenil: aexperiência de familiares de adolescentes e pré-adolescentes. CiêncSaúdeColetiva 14(3): 947-960.

26. Leite SAO, Zanim LM, Granzotto PCD, Heupa S, Lamounier RN (2008) Pontosbásicos de um programa de educaçãoaopaciente com diabetes melitotipo 1. Arq Bras Endocrinol Metab 52 (2): 233-242.

27. Mayor S (2015) Insulin pumps improve glucose control in children with type 1 diabetes, study finds. BMJ 351: h5998.

28. AlokKanungo (2015) Myths about type 1 diabetes: Awareness and education. Indian Journal of Endocrinology and Metabolism 19( Supplement1).

29. The World health organization. Diabetes. https://www.who.int>Health -topics $>$ diabetes.

30. (2010) Textbook of Diabetes, $4^{\text {th }}$ Edition, edited by Richard I G Holt, Clive S Cockram, Allan F and Barry J G, Wiley B.

31. Knowledge- Wikipedia. https://en.m.wikipedia.org>wiki>knowledge.

32. (2017) International Diabetes federation/international society for pediatric and Adolescent Diabetes (IDF) $-8^{\text {th }}$ Edition

33. Zysberg L, Lang T (2015) Supporting parents of children with type 1 diabetes mellitus: a literature review. Patient intelligence 7: 21-31.

34. Sarah S Jaser (2011) Family Interaction in Pediatric Diabetes. Published online: 20 August 2011 \# Springer Science+Business Media, LLC.

35. Torres HC, Pereira FRL, Alexandre LR (2011) Avaliação das açõeseducativasnapromoção do autogerenciamento dos cuidadosem diabetes mellitus tipo 2. Rev Esc Enferm USP 45 (5): 1077-1082.

36. Janica A Drass, Joanne MN, Priscilla C Boykin, Jane M Karen L (1989) Perceived and actual Level of Knowledge of Diabetess Mellitus Among Nurses. DIABETES CARE 12(5).

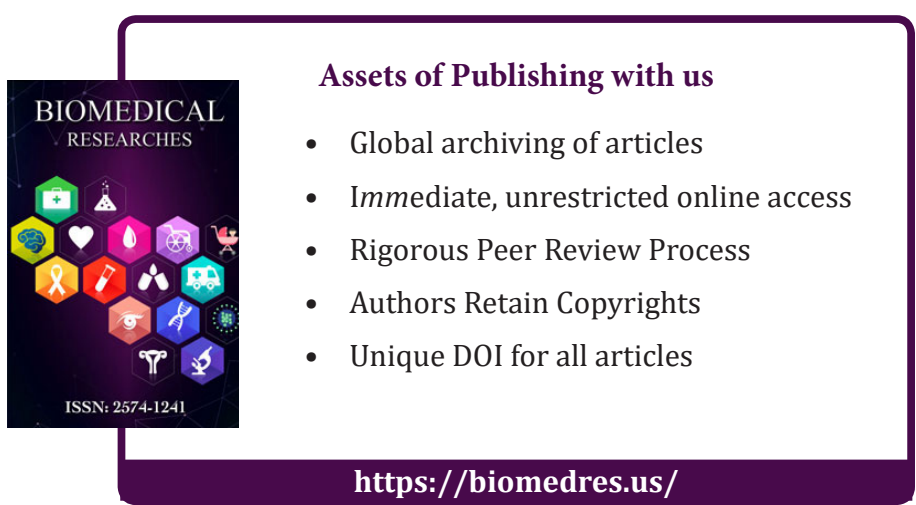

